\title{
A Theoretic Perspective on Critical Communications, Mass Media and Effectual Democracy in Nigeria
}

\author{
Aaron Ola Ogundiwin ${ }^{1}$, Joel N. Nwachukwu ${ }^{1} \&$ Funminiyi Jacob Babajide ${ }^{1}$ \\ ${ }^{1}$ Department of Political Science \& Public Administration, Babcock Univ., Ilishan-Remo, Ogun State, Nigeria \\ Correspondence: Aaron Ola Ogundiwin. E-mail: ogundiwina@babcock.edu.ng
}

Received: June 1, 2020

Accepted: July 1, 2020

Online Published: July 23, 2020

doi:10.5539/ass.v16n8p82

URL: https://doi.org/10.5539/ass.v16n8p82

\begin{abstract}
In contemporary times, democracy has become the political buzzword and, indeed, the basic acceptable form of government with the emergence of liberalism which links democracy with freedom, consent, and political and legal equality. The mass media - which include newspapers, radio and television - play a prominent role in governance and democratic sustainability of any state. In fact, it is a truism that the media serve as the watchdog of governmental activities, ensuring that quality information with which the governed can hold their leaders accountable is made available. The mass media were actively involved in the struggles against colonialism and military rule, as well as the eventual restoration of democratic government in Nigeria. However, in Nigeria, the mass media are fast becoming a pawn in the hands of the government and party in power in particular, and are found in conspiracy with the political elite class in general. This article takes on the contributions of the mass media to effectual democracy in Nigeria. Using agenda setting theoretical framework, it $\mathrm{x}$-rays the effectiveness and shortcomings of the media in delivering on its mandate as the fourth estate of the realm towards ensuring that democratic practices in Nigeria produce the intended result of promoting good and inclusive governance. The paper adopts qualitative research design with data drawn from secondary sources only. It equally uses descriptive and content data analysis. It is found that the mass media have indeed been the middlemen in entrenching democracy in Nigeria but these efforts are being undermined by pecuniary, ownership, political and structural-institutional influences. It is concluded that while the mass media strive to ensure the general inclusion of the populace in the process of governing which fulfills a core democratic tenet, they can do more to overcome the challenges. Among other things, this paper recommends that the government should be deliberate in guaranteeing the freedom of the press to allow for free transmission of information between the government and the people without fear or favour, and likewise, the press should be professional, objective, critical and independent in their reportage, embracing the virtue of investigative journalism.
\end{abstract}

Keywords: democracy, inclusive government, agenda setting, mass media, investigative journalism

\section{Introduction}

Democracy remains a prominent theme in political discourse, not merely as a system of governance, but also as a guide to the relations between the people and the government. This relationship is however facilitated by the mass media which, many a time, perform the functions of the official mouthpiece for both the government and the governed. Galadima and Asemah (2012), cited in Santas and Ogoshi (2016), opine that the mass media is a critical force capable of facilitating the drive towards democratization of any political system. This is inextricably linked to the reality that an effectual democracy largely depends on a well-informed citizenry to thrive. That is, citizens empowered by access to information plus the will to actively participate in public life and the governance of their society. Otherwise, a broad range of the citizenry will be inactive, non-participatory or, at best, parochial in participation, having no access to basic information on the all-important subject of governance.

The media make this "access to information" possible. Critical communication is pivotal to, and indeed one of the hallmarks of, the mass media. Thus, the mass media, because of its perceived monopoly of credible source of news, has profound effect on the people as well as democratic governance. Hence, where such credibility cannot be guaranteed, for whatsoever reason, the relations between the government and the people are doomed to be speculative, conjectural and propaganda-based. Mile (2009:24) envisions an ideal relationship between democracy and the mass media when he asserts that "public dependence on the media gives them the power to set political or democratic agenda and determine which issues will constitute the subject of public debate or 
attract public attention". Most importantly, the mass media remains a veritable agent of socialization through which necessary education and enlightenment on the rights, duties and privileges of the citizens are activated with a view to participating productively in the democratic process, and especially the legitimate decisions of who governs who (or what), when and how. The curious trajectory of democratic experiments in Nigeria and the concomitant critical roles of the mass media as the watchdog and perceived people's conscience provide veritable avenues for an assessment of the significance of the mass media to Nigeria's democratic journey which shall constitute the main thrust of this paper.

\section{Democracy and Democratic Practice in Nigeria}

The concept of democracy as a theory of politics and public decision making, has gained substantial popularity over the years. However, such ideal notion of democracy has been critically challenged, and it is fast receding into archaism, as the realities of the contemporary political systems - especially in developing states - suggest a radical departure from, or a redefinition of, the people-centered model of participation envisaged by such conception. In fact, Oni (2020), while examining the import of democracy and democratic practice in Nigeria, describes it as a misconception for failure to take into cognizance the socio-cultural peculiarities of the political system. In that wise therefore, the concept of democracy has been variously explained by scholars, authors and political analysts. These explanations, which are not necessarily contradictory, point to the single importance of the people (or citizens) in democracy. According to Agbaje (2015:192) democracy "describes an idea, process (series of event leading to change or a course of action) or system of government." He further noted that a system is democratic if it entrenches and expands the right...of people (or concerned stakeholders) in the community to... assume control of their lives through active participation in discussions and decisions on issues and events that affect them and their community" (2015:192). Likewise, what Nwoye (2001) defines as democratic practice is the ability of the people to directly or indirectly choose their representatives. Enemuo (2015:145) further maintains that "democracy denotes a set of ideals, institutions and processes of government that allows the broad mass of the people to choose their leaders". Huntington and Moore (1970), quoted by Agbaje (2015) posits the existence of democracy in any political system where a greater percentage of the people are enabled to participate in the leadership selection process. The most important index of democracy is, therefore, the ability of the people to decide their government and demand its accountability.

It is important to begin with the fact that Nigeria is considered a democratic state, not because of its entrenched democratic institutions, but because of its professed democratic (representative) government which has regrettably been reduced to a periodic four-year electioneering rituals. Nigeria's democratic practice therefore has become a prodigal adventure, returning little or no dividend to the people who ordinarily should constitute the democratic fulcrum. The hydra-headed monster of corruption which has penetrated the societal fabrics has not spared democracy and democratic practice in Nigeria. The commonly, though contested, held philosophy of democracy as the safest form of government, coupled with increasing globalization, and especially America's evangelism of the liberal democratic gospel, ensures that states are increasingly demanding end to dictatorship and dictatorial rule in favour of democracy. This also means that every regime or government (no matter how dictatorial or authoritarian) wants to be clothed with the democratic garment, at least to sustain it or make it appealing to the people. Therefore, despite the oppressive and suppressive rule of the military, which took over power at the early years of independence, concerted efforts were made by individuals, non-governmental organizations and the media to enthrone democratic regime in Nigeria, precisely in May, 1999. While it is a truism in the political lexicon that democracy means rule or government of, by and for the people, not even the acclaimed classical Lincoln's definition of the concept explains who the 'people' are. However, Heater (1964), cited by Enemuo (2015:144), emphasizes basic elements of democracy which include citizens' equality, people's sovereignty, respect for human life, rule of law and personal liberty. Unmistakably, these fundamental cornerstones of democracy - especially the recognition of the people as the source of sovereignty - distinguish it from related concepts in governance.

Although Nigeria has embraced democratic form of government since 1960 when it gained its political independence, the series of crises that bedeviled the country eventually culminated in the military incursion into the country's political space on January 15,1966 . This has been variously attributed to the overwhelming militarization of the then nascent democracy and the politicization of the military. Since then, several dangerous attempts at reengineering and consolidating the democratic process have been instituted, and with little or no return until 1999. The process of deepening of democracy in Nigeria has been characterized by uproar, violence, military interventions, political hopelessness and inept leadership, all to the detriment of the people. The political leadership is not only insensitive to the plights of the people, but also fond of exhibiting anti-democratic traits such as violating the citizens' rights, rule of law and the constitution; and promoting faulty elections and 
electoral process (Pate, 2012). Today, notwithstanding two decades of professed democracy, the political leadership - in and out of power - has not been able to break free from the regimented culture of arbitrariness orchestrated by the military in power characterized by executive fiat and blatant disregard for the rights and choice of the people. Acts of brigandage, misadventures, electoral violence and malpractices, misgovernance, corrupt practices and primitive accumulation of public resources, increased exploitation of state power and gross display of incompetence, constitute a huge barrier to the possibility of citizens' effecting a change of government Indeed, the democratic and political space, having been vehemently monetized and commercialized, has become not only violent but also repugnant to known democratic ethics.

\section{The Mass Media in Nigeria}

Basically, different forms of mass media (traditional, and recently, new media) serve as major avenues for communicating and alerting the masses of Nigeria to the policy decisions of government on almost all public issues. Thus, the emergence of Nigerian mass media can be dated back to the period of 1859 and 1932 (Nkwocha, 1999; Ojenike, 2005; Enemaku, 2005). The first newspaper was established by Rev. Henry Townsend, a Briton, and was called Iwe Iroyin fun awon ara Egba ati Yoruba (A newspaper for the Egbas and Yorubas) in 1859 (Olukotun, 2002).

This newspaper was set up to get the people, mainly indigenous, to access information. Consequent upon the increase in the number of newspapers, the media provide a wider the necessary avenue for the then nationalists and politicians to express themselves. In 1880, some individuals set up the Lagos Times, which constituted a strong voice against colonial rule in Nigeria. In the same vein, the first radio station took off in 1932, when the British Colonial Government opened a Radio Distribution Service (RDS) in Lagos as a transmission channel for British Broadcasting Corporations (BBC) programmes in Nigeria (Sulaiman, 2002). The RDS was later to be renamed the Nigerian Broadcasting Service (NBS) in 1951, which metamorphosed into a full corporation called Nigerian Broadcasting Corporation (NBC) in 1957. This new status was meant to grant it autonomy and insulate it from the influence of government and the ruling elite.

It is important to note that when Nigeria was operating regionalism, the first television station in Nigeria and the whole of Africa - Western Nigerian Television Service (WNTS) - was established in 1959 by the Action Group leader and Western Region Premier, Chief Obafemi Awolowo, after he was denied access to the national radio (Ojenike, 2005). The success of this television service was copied by other regional governments who later set up their own television services. Following this trend, the Federal Government launched an interim global media network in January 1962, later to become a full-fledged agency of the government, now known as Voice of Nigeria (VON), through Decree 15 of 1991 (Nkwocha, 1999; Ojenike, 2005).

Equally, when Decree 32 of 1992 was promulgated by Gen. Babangida, it facilitated private individuals to operate television stations. Hence, television media houses flourished with the opening of eleven (11) privately owned television stations. Others, including African Independent Television (AIT) and Channels Television, were to be established later. This brought about healthy competitions among both private and public television stations across the country which culminates in better and healthy competitive service delivery. Thus, with the trend of time, media ownership became instrument for political propaganda, as many privately-controlled and government-funded media outfits sprang up for political purposes. In other words, the consideration of political leverage became more important for the establishment of media houses than benefits accruable to the populace through unbiased reportage (Duyile, 1987; Uche, 1989). For instance, Chief Obafemi Awolowo's Lagos Daily News and Dr. Nnamdi Azikiwe's West African Pilot became prominent outfits that promote the political interests of the pioneers. Thus, media ownership becomes more competitive and proliferated after independence. In fact, it should be noted, as will be examined later, that the Nigeria media is facing critical challenges occasioned by, for instance, the inclination of the Nigerian leadership towards dictatorship and brutality to the media. However, there is the general consensus that the mass media have been very central to agenda as well as articulation public opinions on vital issues in Nigeria.

\section{Mass Media and Effectual Democracy in Nigeria}

Uyo (1987) cited in Popoola (2004) defines the mass media as the engine of mass communication. That is, the various avenues through which an undifferentiated set of people could be reached at any point through a complex mechanical device - both print and mechanical device - are the mass media. Akinfeleye (2004) conceptualizes the mass media to mean simply the print media. That is, the newspapers, magazines, newsletters, etc. It also refers to the radio, television, cinematography and film. This paper adopts this definition. The media as a group informs (and can equally misinform or 'disinform') the populace. It keeps the people updated and widens societal perspectives on political necessities. 
To fulfill such goals, section 22 of the Constitution of the Federal Republic of Nigeria, 1999 (as amended) provides that the press, radio, television and other agencies of the mass media shall at all times be free to uphold the fundamental objectives contained in its Chapter II, which include holding the government accountable to the government to the people. This section of the constitution recognizes, among other things, the role of mass media as information gatekeepers for the people. This is because government will be denying the citizens one important credentials of democracy by disallowing the freedom of expression and the press. Base on this recognition, Nigerian media have been struggling to ensure that the government fulfils its obligations to the governed. Unfortunately, this ideal provision is strongly limited by the non-justiciable clause in section 6(6)(c) of the same 1999 Constitution, which renders it almost meaningless or at best, a mere rhetoric, except where it can be linked to chapter four of the constitution, especially on human rights to freedom of expression and of press.

The usage of 'fourth estate of the realm', to describe the media is an all-time relevant axiom which explains the role of the press in modern society. Burke was reported to have used it in his address to the British Parliament in 1787 in defence of the sanctity of the press. And globally in contemporary society, the structure of government is configured so that the legislature, executive and judiciary cannot perform efficiently - separately and jointly without the concurrence of the media which creates awareness to the inalienable and inherent rights of the individual, particularly in democracies (Ojo, 2006). We can add that without a vigilant and virile fourth estate (the media), totalitarian leaders with executive power will readily suppress the other organs and clamp down the rights of the citizens under the subterfuge of national interest or some plea of emergency. This is usually the norm in any military regime.

Eziokwu (2004) opines that the idea of media carries an entrenched democratic assumption of possessing constitutional backing like the three known organs of government and portrays modern mass media as neutral reporters. Arguably, Nwosu (2003) and Pate (2012) posit that the mass media have remained in the forefront of the struggle to promote transparent and credible democratic process in Nigeria. However, some sections of the media, especially the soft sell, heightened political tension by publicizing negative prophecies from soothsayers and prophets. The media, in this way, could provoke public rioting, create a culture of public disaffection towards a government or inadvertently provide lessons on spread of disturbance from place to place (McQuail, 1987 cited by Popoola, 2004). Equally, government uses the media not only to portray the legitimacy but also to coax the public that government seeks and pursues the interest of the citizens through its activities.

Where the government has monopolized the media, it uses the media to advance its particularized and idiosyncratic interest, in the guise of public interest. However, in practice, the government is not always able to achieve that degree of control over the media, not even during military regime, thereby resulting to media manipulation and suppression (Ojo \& Adebayo, 2013). Therefore, even during the colonial period, Sadeeq (2006) believes that, the activities of the media, such as the Lagos Daily News and the West African Pilot, made the nationalists' struggle against colonialism and call for independence more widespread and pronounced as the people were exposed to, and mobilized against, the evils of the colonial overlords.

However, the subsequent military intervention in Nigeria's political space about six years after independence brought the media in direct confrontation with the reality of the post-independence Nigeria which, according to Ake (1996), like other West African countries, was essentially arbitrarily violent. Incidence of leadership failure, political antagonism, massive corruption and inordinate desire by the ruling class to suppress oppositions at all cost to retain political power accounted for the series of interventions by the military in governance. In Nigeria, politics has always been seen as a zero-sum game, intended to completely exclude or alienate others. Electoral outcomes have always revealed the widening differences between rival political contenders and between political elite and the people, where power is being secured through the barrel of gun (Abayomi, 2004). However, towards end of 1990s, the media and civil society organizations began to launch social pressure against the junta that was bent on retaining power perpetually.

However, the crucial role of the media in this regard cannot be overemphasized. The media was indeed crucial as catalyst for the struggles against dictatorship and provided impetus and platforms for pro-democratic civil societies by bringing their protests and grievances to the regimes and the people both locally and internationally (Abayomi, 2004).

By and large, the general elections since the return to the present democratic era in 1999 have been intensely covered by all forms of mass media - both print and e-media. The competing political parties, especially the most prominent ones, have been assured of fair coverage with substantial degrees of influence in some media outlets than others depending on ownership and other peculiar considerations. Abuses, irregularities and other political gimmicks were fully documented, monitored and sometimes cautioned. The mainstream media have 
also been found maintaining a deadly neutral stand (between parties) in matters of electoral outcomes, or possibly compromising with the political leadership to support the acceptance of the flawed outcomes of elections rather than canvassing its rejection and/or cancellation. By this, certain acts of electioneering brigandage are either unreported or under-reported. Arguably therefore, the media has been functional, perhaps strengthened, through the transitions from one administration to another since the return to the present democratic dispensation in 1999 (Omoleke \& Olaiya, 2015). In sum, the efforts of the media have helped to deepen the democratic values and consolidate the democratization project in Nigeria. However, deep-seated internal and external challenges continually hamstrung the viability of the media space.

\section{Media Challenges in Nigeria}

There is no doubt that the mass media have been bedeviled with a series of challenges which include the dictatorial stance of the military which the civilian government 'inherited' after the long stay of the military in power. For example, Decree No 4 of 1984 prescribed a two-year jail term for anyone found guilty of publishing false or embarrassing reports against public officers. Professing the truth was not a defense in courts as long as the published story caused 'embarrassment' to a public officer. This decree caught up with two media personnel, both belonging to the Guardian newspaper, Tunde Thompson and Nduka Irabor, who were summarily tried and imprisoned on that basis (Babarinsa, 2019). To perfect this, Decree 22 of 1984 forbade anyone from challenging the legality of Decree No 4, and Decree No 12 of 1985 further ensured that anybody whose conduct is perceived to be a threat to public peace would be detained without trial. Consequently, news media houses such as Concord, Guardian, Newswatch, Punch, Sketch, Observer, among others, were arbitrarily closed. The successive democratic government since 1999, no doubt, exhibits this media censorship to different extent and under different guise. For instance, the BBC News (2014) reported that the Nigerian army raided and searched the delivery vans and vendors of major newspapers - The Leadership, Punch, Nation, daily Trust and Vanguard - in June, 2014, based on the 'order from above'.

Also, insufficient professional personnel, inadequate training, as well as inadequate modern equipment constitute daunting challenges to media effectiveness. This has hindered functional and effective coverage, objective reporting and value-free dissemination of information to meet the need of the people and global trends. Some media houses, especially ones owned by the government, have to make do with analog and pre-modern facilities, worsened by shortage of qualified and trained personnel. Despite the fact that the media also exist to support governments' programmes, they should also, as the people's mouthpiece, provide the citizens with information and present issues that should reflect the diversity of peoples and cultures in Nigeria for peaceful co-existence. Thus, Abayomi (2004) contends that the media (print and electronic) has not been truly deregulated as it remains under the exclusive control of the government and moneybag politicians. For instance, it is a commonplace that during the electioneering periods in Nigeria, the incumbent governments and the oppositions use the media for campaigns, sometimes without recourse to media and democratic ethics. Thus, the modus operandi of the media industries in terms of control by the government has challenged media autonomy and freedom of the press in the Nigeria.

Notably important challenge, inextricably connected with unprofessionalism, is apparent lack of diligence. That is, the attitudes of some media houses to forgo adequate scrutiny of issues before reporting and circulating them to the public. Some media, especially newspapers outlets, have been found reporting 'news' from unverifiable sources, only to turn around to retract same with or without apology. Equally, invariably owing to pressures from either the governments or influential individuals or for the sake of profit or patronage, the traditional responsibility of the media to uncover the capacity, competence, manifestoes and political cum moral antecedents of public office aspirants have been jettisoned. Therefore, incidents of fake news, unverified claims, hate speeches, political propaganda, among others, are common occurrences in the media.

In addition to the foregoing is the prevailing poverty environment where the media operate as well as poor remuneration of media personnel and reporters, making them susceptible to bribery and manipulation. This will not only challenge the effectiveness of the media but also encourage corruption and subservience of the media outfits to the preferences and values of the moneybags, since he who pays the piper equally call the tune and, possibly, dictate the dance. The ugly situation whereby media personnel and journalists are being owed salaries and entitlements for several months by their employers and media owners is not only discouraging and frustrating but also demoralizing.

Perhaps the greatest challenge that confronts the mass media in its critical assessment of any government towards effectual democracy is the overbearing disposition and domineering tendency of Nigerian political elite, especially those in power. The political elite's notoriously intolerant behaviour and reactions to alternative views 
or opinions are usually frightening, which threatens democratic process and values. The 'power by all means' syndrome or 'do or die' political atmosphere ensures that the media are not given the required press freedom. It is difficult, if not impossible, for the media to function effectively in such a violent atmosphere. Instead, sycophancy and praise singing (Pate, 2012) takes the centre stage, especially by the government-owned media and those affiliated with a politician or political party. Similarly, corrupt elements in the society constitute threats to the effectiveness of media activities as such persons - individual and corporate - would spare no effort at concealing their deeds, including intimidating the journalist and pressuring him/her to forgo the possibility of reporting such incident.

\section{Prospects and Challenges of Investigative Journalism in Nigeria}

Investigative journalism is a very crucial precondition for critical communication, and essential for the preservation of a country's democratic institutions. It is indeed paramount in the fight against corruption in Nigeria by helping to beam searchlight on secretive transactions the perpetrators intend to cover up. The National Endowment for Democracy (NED) manual (2016) posits that an investigative journalist should not only be meticulous and thorough in this regard, he/she must also exercise due diligence and patience to successfully accomplish his/her goal. Thus, investigative journalism involves the act of unearthing news and information that somebody or some people want to cover up. This is what Itule and Anderson (2007) described as in-depth researching, digging deeply, interviewing and writing. It is a formidable tool for critical fact-finding and thorough fact-giving. Accordingly, Anyadike (2013) believes the investigative journalist should go the extra mile to break news and discover the intention or motive behind the particular news without waiting for the news from a secondary source. Thus, Ufuophu-Biri (2008:127) is of the opinion that "investigative journalism goes beyond mere reporting of plain and visible facts. It involves digging deep to uncover that which has been hitherto hidden." The distinguishing factor of investigative journalism, according to Ohaja (2011) cited in Anyadike (2013:60), is that: "the report, which must be of public importance, should stem from the finding of a reporter; not a report of an investigation made by someone else. It must also be an issue which those involved are attempting to hide from the public domain".

The media should be accorded the opportunity to act to strengthen democracy and state's institutions. Good governance and accountability thrive on access to valid information, especially from trusted and trustworthy journalists sourced from quality investigations. In fact, the right of the political community to access officially held information, and express their opinions on issues affecting them relating to the conduct of government is an intrinsic part of democracy. Therefore, the singular act of President Goodluck Jonathan signing the Freedom of Information Bill into law in May, 2011 marks a watershed in the quest for public accountability and transparency in Nigeria. In other words, if implemented, this Act will, among other things, affords any interested party the right to request and access information from public officials, agencies and institutions.

This works to further strengthen investigative journalism, as journalists and public advocates have, on this legal basis, severally demanded public declaration of assets and liabilities of public office holders in Nigeria. This has, however, been met with rigorous resistance from the appropriate government agency such as the Code of Conduct Bureau (CCB) which consistently argued in favour of the right of the public office holders to private declaration of assets. Furthermore, what Yusha'u (2009) called pervasive clientelism remains a factor of journalism practice which impedes investigative journalism in Nigeria. This explains the romanticizing between the publishers/media houses and politicians/political office holders with the potential of the journalists serving entrenched political interest rather than public interest. Other notable factors militating against the practice of investigating journalism include poor remuneration, poor working conditions, threats to life and actual physical violence against journalists, ownership influence, corruption within the media and other challenges discussed above.

The case of late Dele Giwa of the Newswatch Magazine who was assassinated through a parcel bomb delivered to his office in October 1986 readily comes to mind among other journalists who had to pay the ultimate price in defense of truth and uncovering the hidden agenda of the government against the people. It would also be recalled that renowned investigative journalist, Agba Jalingo, has been in detention since August 2019 and was subsequently charged with treason by the Cross River State government for alleged malicious publications which actually bothered on the alleged corruption involving Governor Ben Ayade and the Cross River Micro Finance Bank.

In this regard, Olaniya (2008) acknowledges the tendency of a number of journalists in Nigeria to choose to cover up or downplay incriminating evidence/facts concerning the government, institutions and society. This he premised on the fear of being assaulted, detained/tortured or murdered on the altar of "national security". No 
wonder then that despite the increased number of media houses in Nigeria, efforts at investigative journalism have been on decline because of the perceived inherent dangers. The Editor-in-Chief of Daily Nigeria, Jaafar Jaafar, released two video clips of Kano State Governor Abdullahi Ganduje stuffing wads of dollar in his 'babariga' cloth. But that was the end of the news as the case is now effectively dead after the journalist alleged attempts on his life.

\section{Theoretical Framework: Agenda Setting Theory}

The development of agenda setting theory can be traced to Walter Lippmann (1922) who (although did not specifically used the term 'agenda setting) expressed the concern on the vital role that mass media do play in influencing the setting or creation of certain image on the public's mind. However, Maxwell McCombs and Donald Shaw in 1972 popularized the agenda setting theory. The notion of agenda setting was adopted with the examination of the pattern of voting and voters' behaviour in North Carolina, US, during the 1968 presidential election where they found that people often consider issues as critical of discussion where the media presented/reported as such. The media therefore leads in determining the importance that the political society would attach to any issue of public discourse. This theory proposes that the news media play important role in shaping political realities and influencing public opinion.

The amount of time and attention given to an issue and the information relayed in a news story, along with the story's perspective or position, determines how much the readers learn and the degree of importance placed on the issue. Therefore, when the media reflect on the views of a candidate or political party during a campaign, they are also shaping and determining the issues of importance which ultimately set the agenda for a political discourse. The agenda setting theory began as an explanation on how the mass media affect or change the pattern of political behaviour during elections (Cohen, 1963). The two important assumptions of agenda setting theory are; first, the ability of the media and the press to filter and shape (political) reality rather than reflect it. By this, the media is capable of filtering some pieces of information and present it to the public as reality. And second, when the media focuses on just a few issues and subjects, the public tends to perceive those issues as more important.

However, there are external forces that affect media influences such as editors and managers and other external influences. Non- media sources, especially information technology, government officials and influential personnel, have ways of affecting the media and public agenda (Jenkins, 2006; Schivinski \& Dabrowski, 2014). Therefore, the agenda setting theory has been criticized on the grounds that media users are not ideal, they may not pay attention to details, and where they do, they are capable of rational decision and choices to alter the level of awareness, priorities, importance, among others. The mass media's effect is weakened for people who have made up their mind on what constitutes right choice for a particular office (Littlejohn \& Foss, 2009).

This theory is considered relevant to this study due to the substantial impact of the mass media on the Nigerian populace, and how this influences or shapes political behaviour of the people. The Nigerian society relies more on the mass media, particularly radio, television and newspaper, for credible information from, and to, the government. The mass media thus leverage such to influence the people's choices not only during political campaigns and elections but also in pushing important decisions either from the people to the government or from the government to the people. Thus, instances abound where the government influences the people through the media to accept a particular policy, align with an opinion or conform to a particular political behaviour.

\section{Conclusion and Recommendations}

We have been able to establish in this study that the mass media maintain a mutual and inseparable relationship with democracy. In fact, effectual democracy will, by and large, depend on the degree of importance attached to the independence of the media to perform its expected roles. And without vibrant and critical mass media in place, the inclusive and participatory essence of democracy will be defeated at ease. We have also established that the nature of the political environment in which the media operate forms the bedrock of media-democracy analysis. However, by default or design, the Nigerian media have had to operate over the years within a hostile political environment. A barrage of challenges therefore confronts the performance of the critical role of the media in bringing the government to the people and vice-versa. Notwithstanding, the mass media appears to have developed necessary immunity and resistance to withstand the challenges of democratization in Nigeria, thereby becoming an indispensable democratic institution. The mass media is therefore engrafted in the electioneering processes as well as the post-election reality tied to vetting, rationalizing and legitimizing of elections, even when it appears unacceptable to the people. Information about the candidates, political parties and manifestoes are unwind and laid bare for people to express their choices and preferences. Thus, in order to consolidate its democratic mandate, the Nigerian media must strive to overcome the numerous challenges 
limiting its efficiency as a credible institution entrusted to serve as the middleman between the government and the governed.

In this wise, genuine and concerted efforts should be made by all stakeholders to reposition the mass media's image to serve the political community and thus build effectual democracy in Nigeria. This is premised on the ideal that an effective media is as profitable to the sustenance of democratic culture as a compromised media is to the dictatorial tendency of the ruling class. The media should promote investigative journalism towards exposing the societal ills, especially as it affects the practice of democracy. This implies that societal/public interest will take precedence over personal and pecuniary interest. The effort of the British Broadcasting Corporation (BBC) in uncovering issues of sexual advances as gratification for grades in some of Nigerian Universities is therefore commendable. So also we should commend efforts by some media outfits/practitioners to unravel electoral malpractices, institutional scams, financial impropriety and political manoeuvre contrary to the spirit of democracy.

Moreover, towards articulating the interest of the public, the media should provide credible mechanisms to facilitate feedback and monitor prevalent public opinion from the people while channeling same to the government. The media should therefore be consistent in educating and sensitizing the people to their rights and responsibilities while checking the excesses of the government. Rather than whipping up sentiments that fuel instability and violence, the media should take into cognizance the people's peculiar needs and Nigeria's corporate existence in their reportage and coverage. In other words, media practices should enhance community development, democratic peace and national security.

In addition, proper and adequate training and re-training of media personnel and practitioners should be prioritized with the provision of modern and necessary facilities for effective service delivery. That is, the media employers - private or government - should professionalize the media by upgrading it to meet global standard. This should equally be accompanied with substantial remunerative and compensatory pays that would strengthen the media's resolve to unbiased reporting, and boost its morale to pursue of public interest and protection of democracy. This will also give room for critical appraisal of the moral and ethical performance of media practitioners and media houses individually and collectively.

Finally, the media should endeavour always, as a matter of responsibility, to douse political tensions in the country instead of going to town with its explosive and misleading headlines. The media should be skillful in its reportage such that it assures the society of media's sincerity and patriotism, and leave no doubt in the people's mind that the media's professional efforts and conducts indeed reflect the hopes and aspirations of Nigerians towards securing the greater good of the greatest number. As a corollary, therefore, we equally enjoin the government to genuinely respect the people's freedom of expression, freedom of the press and ensure the independence of the mass media to operate legitimately within the ambit of the law without fear or favour.

\section{References}

Abayomi, F. (2004). The Press in Nigerian Emerging Democracy: The Challenges of a New Era. In K. Ajayi, \& B. Ayodele (Eds.), Perspectives on Democracy and Development in Post-Military Nigeria. Ibadan: Julius and Julius Associates.

Adedeji, A. (1998). Democracy, Growth and Development: Lessons of Experience. Ibadan: NES Publishers.

Agbaje, A. (2015). Political Parties and Pressure Groups. In R. Anifowse, \& F. Enemuo (Eds.), Elements of Politics (2nd ed.). Lagos: Sam Iroanusi Publications.

Ake, C. (1996). Democracy and Development in Africa. Ibadan: Spectrum Books Limited.

Akinfeleye, R. A. (2004). Media Machine in Winning Elections, Electoral Violence and the Damage the Journalist can do. Lagos: A Special Publication of UNILAG Sociological Review.

Anyadike, D. O. (2013). Problems and Prospects of Investigative Journalism in Rivers State, Nigeria. A Study of the Tide and Hard Truth Newspapers. Journal of New Media and Mass Communication, 17.

Babarinsa, D. (2019). Be Afraid! Be Very Afraid!! An opinion in The Guardian, December 12, 2019 , para. 5. Retrieved from https://t.guardian.ng/opinion/be-afraid-be-very-afraid/

BBC News. (2014). “Nigerian army raids newspaper depots.” Reported on June 7, 2014. Retrieved from www.bbc.com/news/world-africa-27749024

Cohen, B. C. (1963). The press and foreign policy. Princeton, NJ: Princeton University Press.

Constitution of the Federal Republic of Nigeria. (1999, As Amended). 
Enemuo, F. C. (2015). Democracy, Human Rights and the Rule of Law. In R. Anifowose \& F. Enemuo (Eds.), Elements of Politics (2nd ed.). Lagos: Sam Iroanusi Publications.

Eziokwu, A. S. (2004). Understanding, Practicing \& Sustaining Democracy in Nigeria. Onitsha: Sameza Press.

Itule, B. D., \& Anderson, D. A. (2007). News writing and reporting for today's media. New York: McGraw-Hill

Jenkins, H. (2006). Convergence culture: Where old and new media collide. NYU press.

Lippmann, W. (1922). Public opinion. Transaction Publishers.

McCombs, M. E., \& Shaw, D. L. (1993). The Evolution of Agenda Setting Research: Twenty Five Years in the Marketplace of Ideas. J. of Comm., 43(2), 58-67. https://doi.org/10.1111/j.1460-2466.1993.tb01262.x

McCombs, M., \& Shaw, D. (1972). The Agenda-Setting Function of Mass Media. Public Opinion Quarterly, 36, 176-187. https://doi.org/10.1086/267990

Nwosu, I. (2003). Polimedia: Media and Politics in Nigeria. Enugu: ACCE Publications.

OECD. (2018). The Role of the Media and Investigative Journalism in Combating Corruption. https://doi.org/10.1787/7590ec9d-en

Ojenike, B. (2005). The Nigerian Press. Ibadan: Highland Publishers.

Ojo, E. O. (2006). Fourth Estate of the Realm or Wreck: Media the Government and the Nigerian State. Being the text of a public Lecture delivered at the Herald Excellence and Leadership Development Award (14th June), Ilorin, Kwara State Nigeria.

Ojo, E. O., \& Adebeyo, P. F. (2013). Many 'Sins' of the Mass Media in Nigeria: A Critical Appraisal of the Media in a Decade of Nascent Democracy. Journal of Media and Communication Studies, 5(8), 95-102.

Olaniya, S. C. (2008). Investigative Reporting in Nigeria: The Issues at Stake. A seminar paper presented at the Department of Mass Communication, University of Nigeria, Nsukka.

Olukotun, A. (2002). State Repression, Crisis of Democratization and Media Resistance in Nigeria (1988-1999). Ibadan: College Press Ltd.

Omoleke, I. I., \& Olaiya, T. A. (2015). Democratization Process and Governance Practice in Contemporary Nigeria: A Re-Examination. African Journal of Political Science and International Relations, 9(4), 131-140. https://doi.org/10.5897/AJPSIR2014.0702

Oni, M. A. (2020). Conception and Misconceptions of Majoritarian Democracy and Elections in Nigeria. Being the text of the $31^{\text {st }}$ Inaugural Lecture of Babcock University, Ilishan-Remo.

Oso, I., \& Pate, U. (2010). Mass Media and Society in Nigeria. Lagos: Malthouse Press.

Pate, U. A. (2012, December 15-17). Media and the Process of Democratization in Nigeria. A Paper Presented at a Workshop on the Media and Democracy in Nigeria. Organized by the INEC Press Corps, held at Kaduna.

Popoola, I. S. (2004). The Role of the Mass Media in Reducing Political Violence: A Case Study of the Nigerian 2003 General Elections. UNILAG Journal of Politics, 1(1), pp. 187-208.

Sadeeq, W. (2006). Mass Media and Democracy. In E. O. Ojo (Ed.), Challenges of Sustainable Democracy in Nigeria. Ibadan: John Archers (Publishers) Ltd.

Schivinski, B., \& Dabrowski, D. (2014). The Effect of Social-Media Communication on Consumer Perception of Brands. Journal of Marketing Communications, 2-19. https://doi.org/10.1080/13527266.2013.871323

Ufuophu-Biri, E. (2008). Investigative journalism and the Nigerian society. In V. Agbanu, \& C. Nwabueze (Eds.), Reading in Mass Communication. Enugu: Daisy Press.

Yusha'u, M. (2009). Investigative Journalism and Scandal Reporting in the Nigerian Press. Ecquid Novi: African Journalism Studies, 30(2), 155-174. https://doi.org/10.1080/02560054.2009.9653400

Yusuf, B. (2001). Mass Media in a Constitutional Democracy: The Nigerian Experience, In E. O. Alemika (Ed.), Constitutional Federalism and Democracy in Nigeria. Kaduna: HRM Publications.

\section{Copyrights}

Copyright for this article is retained by the author(s), with first publication rights granted to the journal.

This is an open-access article distributed under the terms and conditions of the Creative Commons Attribution license (http://creativecommons.org/licenses/by/4.0/). 